\title{
Pathological Response and Survival after Neoadjuvant Therapy for Her-2 Positive Breast Cancer
}

\author{
Dan Corneliu Jinga ${ }^{1,2}$, Maria Ruxandra Jinga ${ }^{3 *}$, Adrian Miron ${ }^{4,5}$, Aniela Nodițiti,, Alexandru Blidaru ${ }^{4,6}$ \\ 'University Bucharest Hospital, Department of Medical Oncology, Bucharest, Romania \\ ${ }^{2}$ Neolife Medical Center, Department of Medical Oncology, Bucharest, Romania \\ ${ }^{3}$ Newcastle School of Medical Education, United Kingdom \\ "University of Medicine and Pharmacy "Carol Davila", Bucharest, Romania \\ "University Emergency Hospital Elias, Department of Surgery, Bucharest, Romania \\ ${ }^{6}$ Institute of Oncology "Prof. Dr. Al. Trestioreanu”, Department of Surgical Oncology, Bucharest, Romania
}

*Corresponding author:

Maria-Ruxandra Jinga, MD

Newcastle School of Medical Education

United Kingdom

E-mail: ruxyjinga@gmail.com
Received: 20.02.2021

Accepted: 10.04.2021

\section{Rezumat}

Răspunsul patologic și supraviețuirea în formele de cancer mamar Her-2 pozitiv tratat neoadjuvant

Introducere:În cancerul mamar Her-2 pozitiv, răspunsul patologic complet (pCR) la tratamentul sistemic neoadjuvant constituie un excelent indicator al prognosticului bolii. Procentul pacienților care obțin răspuns în urma tratamentului a fost îmbunătățit ca urmare a utilizării preoperatorii a terapiei anti-Her-2.

Metodă: In perioada 2001 - 2018, am realizat un studiu retrospectiv, pe o populație formată din 56 de pacienți cu cancer mamar Her-2 pozitiv tratat neoadjuvant. Tratamentul a fost administrat în funcție de caracteristicile clinice, patologice şi moleculare ale tumorii şi a cuprins chimioterapie neoadjuvantă în asociere sau nu cu terapia anti-Her-2, urmată de intervenție chirurgicală. Postoperator, tratamentul a fost completat cu radioterapie, modulare endocrină şi terapie anti-Her-2. Scopul principal al studiului a fost calcularea ratei de răspuns patologic complet (pCR) şi a intervalului liber de boală (DFS), acesta din urmă fiind definit ca timpul dintre data intervenției chirurgicale şi momentul aparitiei recidivei bolii sau a decesului indiferent de cauză.

Rezultate: administrarea tratamentului neoadjuvant $\mathrm{s}^{-} \mathrm{a}$ corelat semnificativ statistic atât cu rata pCR, cât şi cu riscul progresiei bolii. A fost identificată şi o corelație între prognosticul rezervat al pacienților şi lipsa tratamentului anti-Her-2 neoadjuvant $(p=0.048)$. DFS median pentru întregul lot studiat a fost de $68 \mathrm{de}$ 
luni. Riscul de progresie a bolii şi deces a fost mai mare la pacienții care nu au obținut răspuns patologic complet în urma tratamentului preoperator.

Rezultate: Rata de răspuns patologic complet (pCR) a întregului lot a fost de 41\%. Subgrupul pacienților tratați neoadjuvant cu terapie anti-Her-2 a prezentat o rată pCR semnificativ mai mare comparativ cu subgrupul celor tratati numai cu citostatice $(p=0.038)$. Aceste observatii sunt în concordanță cu cele obținute în cadrul studiului clinic multicentric randomizat NOAH. Punem în evidență totodată şi rolul terapiei neoadjuvante duale anti-Her-2, precum şi noile abordări în tratamentul postoperator ce au condus la rezultate superioare.

Concluzie: studiul nostru retrospectiv subliniază importanța tratamentului neoadjuvant antiHer-2 în obținerea unui răspuns patologic complet, asociat cu un prognostic favorabil, în formele de cancer mamar Her-2 pozitive.

Cuvinte cheie: cancer mamar Her-2 pozitiv, tratament sistemic neoadjuvant, răspuns patologic complet (pCR), supraviețuire fără semne de boală (DFS), terapie anti-Her-2

\begin{abstract}
Background: Pathological complete response (pCR) after neoadjuvant systemic treatment represents a good surrogate marker for the prognosis of Her-2 positive Breast Cancer (BCs). The results improved after adding anti-Her-2 therapy to chemotherapy in neoadjuvant setting.

Methods: Our retrospective study enrolled a cohort of 56 invasive Her-2 positive non-metastatic BCs treated with neoadjuvant systemic therapy between 2001 and 2018. The patients received neoadjuvant chemotherapy with or without anti-Her-2 therapies before surgery and adjuvant endocrine and anti-Her-2 treatment together with adjuvant radiotherapy, based on clinical, pathological and hormonal receptor expression characteristics. The primary end point was pCR rate and disease-free-survival (DFS), defined as the interval between surgery and documented disease recurrence, progression, or death from any cause.

Results: the rate of pCR for our patients was $41 \%$ independent of type of chemotherapy regimen and the anti-Her-2 therapy used. The results were improved by adding Trastuzumab in the neoadjuvant setting with statistical significance $(p=0.038)$. Median DFS was 68 months for the entire cohort. The risk of recurrence was higher in the group without pCR after neoadjuvant treatment $(52 \%$ vs $17 \% ; p=0.003) .10$ patients died $(18 \%)$, all of them from group without $p C R$. The prognosis at 36 -months was good, with $84 \%$ survival chance at 3 years follow-up.

Conclusion: Our retrospective study underlines the positive impact of neoadjuvant systemic treatment on $\mathrm{pCR}$ rate and on disease-free survival in real-life Her-2 positive breast cancer patients.
\end{abstract}

Key words: Her-2 positive breast cancer, neoadjuvant systemic treatment, pathological complete response (pCR), disease-free-survival (DFS), anti-Her-2 therapy

\section{Introduction}

Between $15-25 \%$ of invasive Breast Cancers (BCs) are human epidermal growth factor receptor 2 (Her-2) positive, defined as showing protein overexpression (3+ on immunohistochemistry) or Her-2 gene amplification proved by in situ hybridization (ISH) techniques.
Together with Estrogen Receptor (ER) and Progesterone Receptor (PR), Her-2 overexpression represents the most important prognostic and predictive factor of response from systemic treatment (1).

Neoadjuvant chemotherapy (NACT) or preoperative systemic therapy was initially introduced for patients with locally advanced 
$\mathrm{BCs}$ to reduce tumor size and facilitate breastconserving surgery (BCT) instead of radical mastectomy (2). Studies have shown no differences in survival between adjuvant orneoadjuvant setting (3).

Pathological complete response (pCR) after NACT represents a surrogate marker prognosis of BC patients, especially for Her-2 positive and triple-negative molecular subtypes $(4,5)$.

The association of chemotherapy with anti-Her-2 treatment in neoadjuvant setting improves the results, increasing pCR rate and disease free-survival rate $(6,7)$.

In Romania, starting from 2015, we used Trastuzumab, a recombinant monoclonal antibody (mAB) (Herceptin; Genentech Inc, South Francisco, CA) and, from March 2020, a dual inhibition between Trastuzumab and Pertuzumab (Perjeta; Genentech Inc, South Francisco, CA) in association with chemotherapy for the neoadjuvant treatment of Her-2 positive BC. Trastuzumab inhibits the Her-2 receptor and Pertuzumab inhibits the dimerization of Her-2 with other Her receptors, which prevents them from signaling in ways that promote cell growth and proliferation (8).

In our retrospective study of a database of patients with invasive non-metastatic BC, we evaluate the $\mathrm{pCR}$ rate after neoadjuvant systemic treatment (NAST) and the impact of $\mathrm{pCR}$ on the prognosis of Her-2 positive BC as primary endpoint. We then highlight the importance of adding anti-Her-2 treatment to neoadjuvant chemotherapy and the importance of completed Her-2 inhibition after surgery in terms of prognosis, especially for the pCR positive group. Finally, we touch on the importance of changing therapy after surgery for the pCR negative group, in correlation with the new approval for antiHer-2 therapy in the National Guideline.

\section{Patients and Methods}

\section{Patients}

A total of 56 invasive non-metastatic BCs with Her-2 IHC $3+$ or IHC 2+ and FISH positive received neoadjuvant systemic therapy between 2001 and 2018 at The Institute of Oncology, University Bucharest Hospital and Neolife Medical Center. Clinical and histopathological data were extracted from the patient database of our team.

Immunohistochemical stains for ER, PR and Her-2 were performed at the time of the initial diagnosis. We excluded the cases diagnosed by fine-needle aspiration cytology of the tumor, especially from 2001-2004. The cut-off for ER and PR positivity was considered $\geq 10 \%$. Her- 2 was examined either with immunohistochemistry or in situ hybridization (ISH) techniques (FISH, SISH, DISH). An immunohistochemical result of $3+$ was considered positive; the $2+$ cases were considered positive only when unequivocally amplified by ISH techniques.

\section{Treatment}

The neoadjuvant chemotherapy regimens varied over the 17 years. We classified the type of treatment in 3 categories: anthracycline and taxane based therapy (concomitant or sequential), anthracycline without taxane and non-anthracycline therapy.

Regarding anti-Her-2 therapies, the patients received Trastuzumab starting from March 2015, according with the National Guideline. 5 patients received dual anti-Her-2 inhibition with Trastuzumab and Pertuzumab.

Surgery was performed following neoadjuvant treatment; sequentially the patients received adjuvant anti-her-2 treatment, adjuvant radiotherapy and endocrine therapy according with clinical and pathological characteristics of the disease.

The response was determined by microscopic examination of the excised tumor and lymph nodes after completion of neoadjuvant treatment. pCR was defined as the absence of invasive carcinoma in the breast resection specimen and lymph nodes (ypT0/is ypN0) for patients who underwent breast surgery and axillary lymph node dissection (ALND).

\section{Study Endpoint}

The primary end point was $\mathrm{pCR}$ rate and 
disease-free-survival (DFS), defined as the interval between surgery and documented disease recurrence, progression, or death from any cause.

\section{Statistical Analysis}

Statistical analysis was performed using Medcalc software version 19.7. All categorical variables were presented as number and percentage and compared with Chi-square Test or Fisher's Exact test. For continuous variables, after a normality check, means and SD or median were used and proper parametric or non-parametric test for comparisons were employed. We also used a correlation analysis (Spearman's Rho coefficient was calculated). A $p<0.05$ was considered significant for all tests.
Kaplan-Meier method with long-rank estimates was used to test the prognostic effect of pCR and the prognostic effect of (neo)adjuvant treatment use on DFS.

\section{Results}

A total of 56 Her-2 positive BC patients were treated with neoadjuvant systemic therapy; 41\% (23 patients) achieved pCR after NAST and 59\% (33 patients) did not. The median age of the population of the study was 48 years. 31 patients $(55 \%)$ were premenopausal and 25 (45\%) postmenopausal. The characteristics of the cohort are depicted in Table 1.

39 patients $(70 \%)$ received chemotherapy combined with anti-Her-2 therapy in neoadjuvant setting and $42(75 \%)$ received

Tabel 1. Clinicopathological characteristics of the patient's cohort

\begin{tabular}{|c|c|c|c|c|c|}
\hline Parameter & & $\begin{array}{c}\text { Total } \\
\text { (56 patients) }\end{array}$ & $\begin{array}{c}\text { Group A - pCR present } \\
\text { (23 patients) } \\
(41 \%)\end{array}$ & $\begin{array}{c}\text { Group B - pCR absent } \\
\text { (33 patients) } \\
\text { (59\%) }\end{array}$ & T-test \\
\hline Age (years) & & 48.4 & 48.21 & 48.63 & $p=0.904$ \\
\hline Menopausal status & $\begin{array}{l}\text { pre } \\
\text { post }\end{array}$ & $\begin{array}{l}31(55 \%) \\
25(45 \%)\end{array}$ & $\begin{array}{l}12(52 \%) \\
11(48 \%)\end{array}$ & $\begin{array}{l}19(57 \%) \\
14(43 \%)\end{array}$ & $p=0.695$ \\
\hline Histological grade & $\begin{array}{l}\text { G1/G2 } \\
\text { G3 }\end{array}$ & $\begin{array}{l}26(46 \%) \\
30(54 \%)\end{array}$ & $\begin{array}{l}13(57 \%) \\
10(43 \%) \\
\end{array}$ & $\begin{array}{l}13(40 \%) \\
20(60 \%)\end{array}$ & $p=0.133$ \\
\hline T stage (clinical) & $\begin{array}{l}\text { cT1 } \\
\text { cT2 } \\
\text { cT3 } \\
\text { cT4 }\end{array}$ & $\begin{array}{c}3(5 \%) \\
25(45 \%) \\
12(21 \%) \\
16(29 \%) \\
\end{array}$ & $\begin{array}{c}2(9 \%) \\
12(52 \%) \\
5(22 \%) \\
4(17 \%) \\
\end{array}$ & $\begin{array}{c}1(3 \%) \\
13(40 \%) \\
7(21 \%) \\
12(36 \%) \\
\end{array}$ & $p=0.093$ \\
\hline $\bar{N}$ stage (clinical) & $\begin{array}{l}\mathrm{cNO} \\
\mathrm{cN}+\end{array}$ & $\begin{array}{c}9(16 \%) \\
47(84 \%)\end{array}$ & $\begin{array}{c}3(13 \%) \\
23(87 \%)\end{array}$ & $\begin{array}{c}6(18 \%) \\
27(82 \%)\end{array}$ & $p=0.614$ \\
\hline ER status & $\begin{array}{l}\text { positive } \\
\text { negative }\end{array}$ & $\begin{array}{l}39(70 \%) \\
17(30 \%)\end{array}$ & $\begin{array}{c}15(65 \%) \\
8(35 \%)\end{array}$ & $\begin{array}{c}24(72 \%) \\
9(28 \%)\end{array}$ & $p=0.556$ \\
\hline PR status & $\begin{array}{l}\text { positive } \\
\text { negative }\end{array}$ & $\begin{array}{l}36(64 \%) \\
20(36 \%)\end{array}$ & $\begin{array}{c}15(65 \%) \\
8(35 \%) \\
\end{array}$ & $\begin{array}{l}21(64 \%) \\
12(36 \%) \\
\end{array}$ & $p=0.905$ \\
\hline Neoadjuvant treatment & $\begin{array}{l}\text { chemo alone } \\
\text { chemo + anti-Her-2 } \\
\text { chemo + dual anti-Her-2 } \\
\text { anti-Her-2 alone }\end{array}$ & $\begin{array}{c}17(30 \%) \\
38(68 \%) \\
1(2 \%) \\
0 \\
\end{array}$ & $\begin{array}{c}7(30 \%) \\
15(65 \%) \\
1(5 \%) \\
0 \\
\end{array}$ & $\begin{array}{c}10(30 \%) \\
23(70 \%) \\
0 \\
0 \\
\end{array}$ & $p=0.038$ \\
\hline Chemotherapy regimens & $\begin{array}{l}\text { anthracyclines and taxanes } \\
\text { anthracyclines without taxanes } \\
\text { non-anthracyclines }\end{array}$ & $\begin{array}{l}42(74 \%) \\
7(13 \%) \\
7(13 \%) \\
\end{array}$ & $\begin{array}{l}16(70 \%) \\
3(13 \%) \\
4(17 \%)\end{array}$ & $\begin{array}{c}26(79 \%) \\
4(12 \%) \\
3(9 \%) \\
\end{array}$ & $p=0.144$ \\
\hline Surgery & $\begin{array}{l}\text { breast conserving therpy } \\
\text { radical mastectomy } \\
\text { No surgery }\end{array}$ & $\begin{array}{c}7(13 \%) \\
46(82 \%) \\
3(5 \%) \\
\end{array}$ & $\begin{array}{c}5(22 \%) \\
18(78 \%) \\
0 \\
\end{array}$ & $\begin{aligned} & 2(6 \%) \\
& 28(85 \%) \\
& 3(9 \%) \\
&\end{aligned}$ & \\
\hline Radiotherapy & $\begin{array}{l}\text { Yes } \\
\text { No }\end{array}$ & $\begin{array}{l}46(82 \%) \\
10(18 \%)\end{array}$ & $\begin{array}{c}18(78 \%) \\
5(22 \%)\end{array}$ & $\begin{array}{c}28(85 \%) \\
5(15 \%)\end{array}$ & \\
\hline Adjuvant Anti-Her-2 therapy & $\begin{array}{l}\text { Yes (Trastuzumab) } \\
\text { Yes (dual therapy) } \\
\text { No }\end{array}$ & $\begin{array}{l}45(80 \%) \\
5(9 \%) \\
6(11 \%)\end{array}$ & $\begin{array}{c}17(74 \%) \\
4(17 \%) \\
2(9 \%)\end{array}$ & $\begin{array}{c}28(85 \%) \\
1(3 \%) \\
4(12 \%)\end{array}$ & $p=0.114$ \\
\hline Adjuvant endocrine therapy & $\begin{array}{l}\text { Yes } \\
\text { No }\end{array}$ & $\begin{array}{l}46(82 \%) \\
10(18 \%)\end{array}$ & $\begin{array}{c}18(78 \%) \\
5(22 \%)\end{array}$ & $\begin{array}{c}28(85 \%) \\
5(15 \%)\end{array}$ & \\
\hline
\end{tabular}


anthracycline-taxane based chemotherapy. 50 patients (90\%) received adjuvant anti-Her-2 therapy after breast surgery.

The regression analysis did not show any correlation between the $\mathrm{pCR}$ rate and menopausal status, histological grade (G), clinical $\mathrm{T}$ and $\mathrm{N}$ stage, ER and $\mathrm{PR}$ expression and type of NACT used ( $\mathrm{p}>0.05$ ) (Table 1).

The pCR rate was correlated with neoadjuvant systemic treatment administration $(p=0.038$ (Table 1). The Kaplan-Meier method confirmed the impact of $\mathrm{pCR}$ on disease-freesurvival $(\mathrm{p}=0.023)$ (Fig. 1).

The treatment did not differ between the groups (group A with pCR and group B without $\mathrm{pCR}$ ) with respect to neoadjuvant and adjuvant systemic treatment, type of surgery and adjuvant radiotherapy (Table 1). The medium time between the start of neoadjuvant treatment and surgery was 189 days. $21(38 \%)$ patients had a recurrence of disease with a median DFS of 68 months for the entire cohort, with only 4 (17\%) patients from group A and 17 patients from group B $(52 \%)$, with statistically significant differences between the two groups $(\mathrm{p}=0.003)$. 10 patients died (18\%), all of them from group B (Table 2).

The neoadjuvant treatment was correlated with risk of disease progression; lack of antiHer-2 treatment was correlated with poor prognosis $(r=0,27 ; p=0.048)$.

The responders with $\mathrm{pCR}$ after neoadjuvant systemic treatment (group A), had a phenotype represented by: G1/G2 histologic grade (more than 50\%), $\mathrm{T} 1$ and $\mathrm{T} 2$ clinical stages $(60 \%)$, more HR negative disease $(35 \%)$

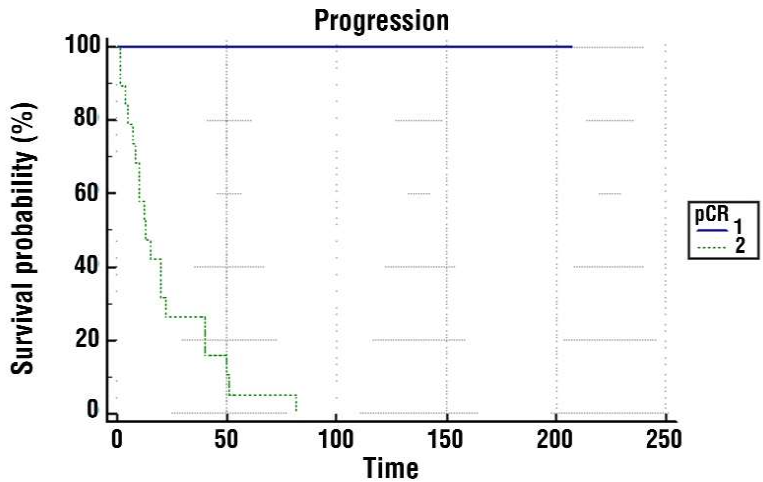

Figure 1. Kaplan-Meier analysis to test the prognostic effect of the pCR on DFS

compared with non-responders, without pCR (group B) with G3 histological grade (60\%), T3 and T4 clinical stages (60\%) HR positive disease (more than 70\%) phenotype (Table 1).

For group A, we identified a statistically significant correlation between neoadjuvant $(r=0,75 ; p<0.001)$ and adjuvant systemic treatment $(\mathrm{r}=0,54 ; \mathrm{p}=0.09)$ and survival without recurrence.

For group B, the risk of disease progression and risk of death were correlated with antiHer-2 neoadjuvant treatment $(\mathrm{r}=0,42 ; \mathrm{p}=0,047$ for progression and $\mathrm{r}=0,42 ; \mathrm{p}=0,014$ for risk of death).

50 patients $(90 \%)$ received adjuvant antiHer-2 treatment, according to the National Guidelines, with 45 patients receiving Trastuzumab and 5 patients dual Her-2 inhibition with Trastuzumab and Pertuzumab. The Kaplan-Maier survival analysis showed a positive impact on the survival of patients

Tabel 2. Survival parameters

\begin{tabular}{|c|c|c|c|c|}
\hline Parameter & $\begin{array}{l}\text { Total cohort } \\
\text { (56 patients) }\end{array}$ & $\begin{array}{l}\text { PCR positive } \\
\text { (23 patients) }\end{array}$ & $\begin{array}{l}\text { PCR absent } \\
\text { (33 patients) }\end{array}$ & $p$ \\
\hline Time from diagnostic to surgery (Days) & $\begin{array}{c}189 \\
(89-339)\end{array}$ & $\begin{array}{c}178 \\
(92-230)\end{array}$ & $\begin{array}{c}189 \\
(89-339) \\
\end{array}$ & \\
\hline $\begin{array}{c}\text { Progression } \\
\text { No } \\
\text { Yes }\end{array}$ & $\begin{array}{l}35(62 \%) \\
21(38 \%)\end{array}$ & $\begin{array}{c}19(83 \%) \\
4(17 \%)\end{array}$ & $\begin{array}{l}16(48 \%) \\
17(52 \%)\end{array}$ & $p=0.003$ \\
\hline Disease free survival (months) & $\begin{array}{c}179 \\
(0-1423) \\
\end{array}$ & $\begin{array}{c}78 \\
(5-207) \\
\end{array}$ & $\begin{array}{c}197 \\
(0-1423) \\
\end{array}$ & $p=0.122$ \\
\hline Overal survival (months) & $\begin{array}{c}68 \\
(26-251)\end{array}$ & $\begin{array}{c}86 \\
(27-251)\end{array}$ & $\begin{array}{c}55 \\
(26-141)\end{array}$ & \\
\hline Death & $10(18 \%)$ & 0 & $10(30 \%)$ & $p=0.003$ \\
\hline
\end{tabular}


treated with adjuvant anti-Her-2 therapy.

The prognosis at 36 -months was good, with $84 \%$ survival chance at 3 years follow-up and no significant differences between the group A with pCR present (87\%) and group B without pCR (82\%) (Table 3).

\section{Discussion}

Our retrospective 17-years study enrolled a young non-metastatic invasive $\mathrm{BC}$ population. The median age of population was 48 yearsold, compared with 62 years-old from the Surveillance Epidemiology End Results (SEER) database (9).

Neoadjuvant chemotherapy (NACT) was initially introduced for inoperable locally advanced BC patients. Over time, NACT indication was expanded after the demonstration that it increases breast-conserving surgery rate and after the clinical trials showed the same survival results with adjuvant treatment. In addition, neoadjuvant therapy provides information about tumor response in vitro and offers support for treatment adjustment after surgical resection of the tumor.

Pathological complete response (pCR) after NACT represents a surrogate marker prognosis of BC patients.

In our study cohort, $70 \%$ of the patients received chemotherapy combined with anti-Her-2 therapy in neoadjuvant setting, especially from 2015, the date of approval of Trastuzumab for this indication in Romania. $90 \%$ of patients received adjuvant anti-Her-2 therapy after breast surgery, in accordance with National Guidelines.

The rate of pCR for our patients was $41 \%$ independent of the type of chemotherapy regimen and the anti-Her-2 therapy used. The results were improved by adding Trastuzumab in the neoadjuvant settingwith statistical significance $(p=0.038)$. These results are consistent with the NOAH trial, which shows an increased rate of pCR from 19 to $38 \%$ by adding Trastuzumab (10).

The results could be improved with dual Her-2 inhibition (Trastuzumab and Pertuzumab). The pCR rate increased to 50$70 \%$ according with the main clinical trials (Tryphaena, Berenice, Train-2 and Kristine trial) (11-14). In our cohort only 1 of 56 patients received neoadjuvant dual inhibition, as the combination was approved after 2018 in our National Guidelines.

Disease-free survival was strongly associated with pathological complete remission. The rate of reccurrence was $38 \%$ for the entire cohort and $17 \%$ for the patients with $\mathrm{pCR}$ compared with $52 \%$ for the patients without pCR, irrespective of the type of neoadjuvant treatment. The median DFS was 68 months. None of the patients from the pCR group had died at 36-months follow-up compared with 10 deaths $(30 \%)$ in the group without $\mathrm{pCR}(\mathrm{p}=0.003)$.

The adjuvant treatment after surgery is also very important. Our survival analysis showed a positive impact on the survival of the patients treated in adjuvant setting. 90\% of patients received anti-Her-2 treatment and 5 of them dual anti-Her-2 inhibition, independently of the pathological response. This treatment was consistent with European and National Guidelines in March 2018, the cut-off date for our study.

Starting from 2021, the type of adjuvant treatment administered depends on pCR status.

For the pCR positive group, our study, consistent with literature data, showed the positive impact on survival of adjuvant Trastuzumab treatment with or without association with Pertuzumab. Different

Table 3. Disease free survival rate at 1,2 or 3 years from the end of the neoadjuvant treatment

\begin{tabular}{lccccc}
\hline Event disease related & $\mathbf{6}$ months & $\mathbf{1 2}$ months & $\mathbf{1 8}$ months & $\mathbf{2 4}$ months & $\mathbf{3 6}$ months \\
\hline Total & 53 & $52(93 \%)$ & 49 & $47(84 \%)$ & $47(84 \%)$ \\
\hline pCR present $(23)$ & 21 & $21(91 \%)$ & 20 & $20(87 \%$ & $20(87 \%)$ \\
\hline pCR absent (33) & 32 & $31(94 \%)$ & 29 & $27(82 \%)$ & $27(82 \%)$ \\
\hline
\end{tabular}


researchers suggest a de-escalation of treatment for the patients treated with neoadjuvant Trastuzumab and Pertuzumab. They recommend completing a one year of Trastuzumab treatment for the patient with $\mathrm{pCR}$. More data is needed to reach a definitive conclusion. Current guidelines recommend the same treatment in neo and adjuvant setting, depending on the cardiac status of the patient.

For the pCR absent group with poor prognosis, we have some new data. For the patients treated with neoadjuvant Trastuzumab with or without Pertuzumab and without pCR, the switch with TD-M1 (ado-Trastuzumab emtansine/Kadcyla - Genentech/Roche) in adjuvant setting could improve the local rate and distant rate of the reccurrence, as Phase 3 KATHERINE trial demonstrated (15). Starting from February 2021, we have this opportunity for Romanian patients, in accordance with the updated National Guidelines.

Our cohort study had some limitations: the small number of the patient population did not allow us to make a comparison between Luminal B (HR positive / Her-2 positive) and enriched Her-2 (HR negative / Her-2 positive) BCs. In addition, the patients were treated before 2018; at that time we did not have the opportunities to treat all suitable patients with dual Her-2 inhibition. The short follow up time (only 36 months) did not allow us to have a good overall survival data of the cohort.

We plan to increase our follow up period to 5 years and to introduce the cohort of patients treated after 2018.

\section{Conclusion}

The results of our retrospective cohort study underline the positive impact of neoadjuvant systemic treatment (chemotherapy in combination with anti-Her-2 therapy) on pCR rate and on disease free-survival in real-life Her-2 positive breast cancer patients. The study also highlights the unmet treatment needs for the pCR absent group of patients. We hope to improve results with the new generation of antiHer-2 therapies.

\section{Conflict of Interest}

The authors declare no conflicts of interests.

\section{References}

1. Sorliea T, Peroua CM, Tibshiranien R, Aas T, Geisler S, Johnsen H, et al. Gene expression patterns of breast carcinomas distinguish tumor subclasses with clinical implications. Proc Natl Acad Sci U S A. 2001;98(19):10869-74.

2. Kaufmann M, Hortobagyi G.N, Goldhirsch A, Scholl S, Makris A, Valagussa $P$, et al Recommendations from an international expert panel on the use of neoadjuvant (primary) systemic treatment of operable breast cancer: an update. J Clin Oncol. 2006;24(12): 1940-9.

3. Mauri D, Pavlidis N, Ioannidis J.P.A. Neoadjuvant versus adjuvant systemic treatment in breast cancer: a meta-analysis. J Natl Cancer Inst. 2005; 97(3):188-94.

4. Berruti A, Amoroso V, Gallo F, Bertaglia V, Simoncini E, Pedersini R, et al. Pathological complete response as a surrogate for the clinical outcome in patients with breast cancer after neoadjuvant therapy: a meta-analysis of 29 randomized prospective studies. J Clin Oncol. 2014;32(34):3883-91.

5. Broglio KR, Quintana M, Foster M, Olinger M, McGlothlin A, Berry SM, et al. Association of pathological complete response to neoadjuvant therapy in Her-2 positive breast cancer with long-term outcomes: a meta-analysis. JAMA Oncol. 2016;2(6):751-60.

6. Takada M, Ishiguro N, Nagai S, Ohtani S, Kawabata H, Yanagita Y, et al. Survival of Her2-positive primary breast cancer patients treated by neoadjuvant chemotherapy plus trastuzumab study (JBCRG-C03 study". Breast Cancer Res Treat. 2014;145(1):143-53.

7. Cortazar P, Zhang L, Untch M, Mehta K, Costantino JP, Wolmark N, et al. Pathological complete response and long-term clinical benefit in breast cancer: the CTNeoBC pooled analysis. Lancet. 2014;384(9938):164-72.

8. Harbeck N, Beckmann MW, Rody A, Schneeweiss A, Müller V, Fehm T, et al. HER2 Dimerization Inhibitor Pertuzumab - Mode of Action and Clinical Data in Breast Cancer. Breast Care (Basel). 2013;8(1):49-55.

9. American Cancer Society. Breast Cancer Facts \& Figures 2019-2020. Atlanta: American Cancer Society, Inc. 2019.

10. Gianni L, Eiermann W, Semiglazov V. Neoadjuvant chemotherapy with trastuzumab followed by adjuvant trastuzumab versus neo-adjuvant chemotherapy alone, in patients with HER2-positive locally advanced breast cancer (the NOAH trial): a randomised controlled superiority trial with a parallel HER2-negative cohort. Lancet. 2010;375(9712):377-84.

11. Schneeweiss A, Chia S, Hickish T, V Harvey, A Eniu, R Hegg, et al. Pertuzumab plus trastuzumab in combination with standard neoadjuvant anthracycline-containing and anthracycline-free chemotherapy regimens in patients with Her-2 positive early breast cancer: a randomized phase II cardiac safety study (TRYPHAENA). Ann Oncol. 2013;24(9):2278-84.

12. Swain SM, Ever MS, Viale G, Delaloge S, Ferrero J-M, Verrill M, et al. Pertuzumab, trastuzumab and standard anthracycline and taxane-based chemotherapy for the neoadjuvant treatment of patients with Her-2 positive localized breast cancer (BERENICE): a phse II, open-label, multicenter, multinational cardiaca safety study. Ann Oncol. 2018;29(3):646-653.

13. van Ramhorst MS, van der Voort A, van Werkhoven ED, Mandjes IA, Kemper I, Dezentjé V0, et al. Neoadjuvant chemotherapy with or without antracyclines in the presence of dual Her2 blockade for Her-2-positive breast cancer (TRAIN-2): a multi-centre, open-label, randomized, phase 3 trial. Lancet Oncol. 2018;19(12):1630-1640.

14. Hurvitz SA, Martin M, Symmans WF, et al. Pathologic complete response (pCR) rates after neoadjuvant trastuzumab emtansine (T-DM1 $[\mathrm{K}])+$ pertuzumab $(P)$ vs docetaxel + carboplatin + trastuzumab $+P(T C H P)$ treatment in patients with HER2-positive (HER2+) early breast cancer (EBC) (KRISTINE). J Clin Oncol. 2016; (suppl; abstr 500).

15. von Minckwitz G, Huang CS, Mano MS, Loibl S, Mamounas EP, Untch M, et al. Trastuzumab emtansine for residual invasive Her-2-positive breast cancer. N Engl J Med. 2019;380(7):617-628. Epub 2018 Dec 5. 